This article was downloaded by: [Universidad Autónoma del Estado de México], [Gutierrez-Segura Edith] On: 08 July 2014, At: 11:38

Publisher: Taylor \& Francis

Informa Ltd Registered in England and Wales Registered Number: 1072954 Registered office: Mortimer House, 37-41 Mortimer Street, London W1T 3J H, UK

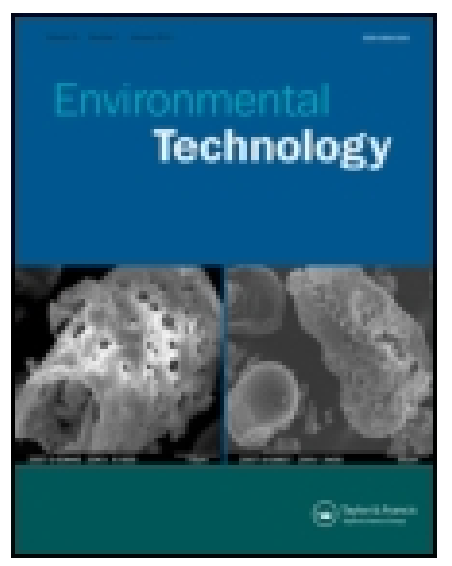

\title{
Environmental Technology
}

Publication details, including instructions for authors and subscription information:

http:// www. tandfonline.com/loi/tent20

\section{Efficient removal of crystal violet dye from aqueous solutions by vitreous tuff mineral}
A. Blanco-Flores ${ }^{\mathrm{ab}}$, A. Colín-Cruz ${ }^{\mathrm{a}}$, E. Gutiérrez-Segura ${ }^{\mathrm{a}}$, V. Sánchez-Mendieta ${ }^{\mathrm{a}}$, D. A. Solís- Casados $^{c}$, M.A. Garrudo-Guirado ${ }^{b} \&$ R. Batista-González ${ }^{d}$
a Facultad de Química, Universidad Autónoma del Estado de México, Paseo Colón y Tollocan s/ n. C.P. 50180 Toluca. Estado de México, Mexico.
${ }^{\text {b }}$ Facultad de Ingeniería Química, Instituto Superior Politécnico J osé Antonio Echeverría, calle 114 No. 11901 entre 119 y 127, Marianao, La Habana, Cuba
c Centro Conjunto de Investigación en Química Sustentable UAEM-UNAM, Carretera Toluca, Atlacomulco Km 14.5, Unidad San Cayetano, Toluca, Estado de México, Mexico
d Instituto de Geología y Paleontología, Carretera Vía Blanca No. 1002 y Línea del Ferrocarril, San Miguel del Padrón, La Habana, Cuba
Published online: $15 \mathrm{~J}$ an 2014.

To cite this article: A. Blanco-Flores, A. Colín-Cruz, E. Gutiérrez-Segura, V. Sánchez-Mendieta, D. A. Solís-Casados, M.A. Garrudo-Guirado \& R. Batista-González (2014) Efficient removal of crystal violet dye from aqueous solutions by vitreous tuff mineral, Environmental Technology, 35:12, 1508-1519, DOI: 10.1080/ 09593330.2013.871352

To link to this article: http:// dx.doi.org/ 10.1080/09593330.2013.871352

\section{PLEASE SCROLL DOWN FOR ARTICLE}

Taylor \& Francis makes every effort to ensure the accuracy of all the information (the "Content") contained in the publications on our platform. However, Taylor \& Francis, our agents, and our licensors make no representations or warranties whatsoever as to the accuracy, completeness, or suitability for any purpose of the Content. Any opinions and views expressed in this publication are the opinions and views of the authors, and are not the views of or endorsed by Taylor \& Francis. The accuracy of the Content should not be relied upon and should be independently verified with primary sources of information. Taylor and Francis shall not be liable for any losses, actions, claims, proceedings, demands, costs, expenses, damages, and other liabilities whatsoever or howsoever caused arising directly or indirectly in connection with, in relation to or arising out of the use of the Content.

This article may be used for research, teaching, and private study purposes. Any substantial or systematic reproduction, redistribution, reselling, loan, sub-licensing, systematic supply, or distribution in any form to anyone is expressly forbidden. Terms \& Conditions of access and use can be found at http:// www.tandfonline.com/page/terms-and-conditions 


\title{
Efficient removal of crystal violet dye from aqueous solutions by vitreous tuff mineral
}

\author{
A. Blanco-Flores ${ }^{\mathrm{a}, \mathrm{b}}$, A. Colín-Cruz ${ }^{\mathrm{a} *}$, E. Gutiérrez-Segura ${ }^{\mathrm{a}}$, V. Sánchez-Mendieta ${ }^{\mathrm{a}}$, D.A. Solís-Casados ${ }^{\mathrm{c}}$, \\ M.A. Garrudo-Guirado ${ }^{\mathrm{b}}$ and R. Batista-González ${ }^{\mathrm{d}}$ \\ ${ }^{a}$ Facultad de Química, Universidad Autónoma del Estado de México, Paseo Colón y Tollocan s/n. C.P. 50180 Toluca, Estado de \\ México, Mexico, ${ }^{b}$ Facultad de Ingeniería Química, Instituto Superior Politécnico José Antonio Echeverría, calle 114 No. 11901 entre \\ 119 y 127, Marianao, La Habana, Cuba; ${ }^{c}$ Centro Conjunto de Investigación en Química Sustentable UAEM-UNAM, Carretera Toluca, \\ Atlacomulco Km 14.5, Unidad San Cayetano, Toluca, Estado de México, Mexico; ${ }^{d}$ Instituto de Geología y Paleontología, Carretera Vía \\ Blanca No. 1002 y Línea del Ferrocarril, San Miguel del Padrón, La Habana, Cuba
}

(Received 6 September 2013; accepted 23 November 2013)

\begin{abstract}
Textural, structural and morphological characteristics of the vitreous tuff were determined by means of several physicochemical techniques. The nitrogen adsorption isotherm at $77 \mathrm{~K}$ was fitted with the Brunnauer-Emmet-Teller model and together with the results of the average pore distribution showed a mesoporous material. Samples of vitreous tuff were used as adsorbent to study the removal of crystal violet from aqueous solution. The presence of -OH moieties in the material seems to be responsible for the removal of the dye showing that vitreous tuff can be used as an organic dye adsorbent material. The pseudo-second-order model was the best fit model for describing the sorption process of crystal violet; intraparticle diffusion being the controlling step in the process. The experimental adsorption isotherm was fitted with Langmuir, Freundlich and Langmuir-Freundlich models, showing better correlation with the second one. The adsorption capacity was $170.01 \mathrm{mg} / \mathrm{g}$, being among the highest compared with other inorganic and organic common sorbent materials. The design of single stage of the adsorber can predict the behaviour to potential scale up. This mineral has a very good potential as an adsorbent material for organic dyes.
\end{abstract}

Keywords: crystal violet; tuff; adsorption; water contamination; adsorbent material

\section{Introduction}

The textile industry is characterized by using complex and toxic organics compounds in its production processes, which then become waste and end up in the industrial wastewaters. It has been estimated that about 10,000 of different commercial dyes and pigments exist; over $7 \times 10^{5}-1 \times 10^{6}$ ton are produced annually worldwide, and approximately $10-15 \%$ is lost in the effluent during the dyeing processes.[1] The discharge of waste, where these contaminants are present, deteriorates water quality since water acquires colouration blocking light and inhibiting the photosynthesis process occurring in aquatic environments.[2]

Crystal violet is widely used for dyeing in the textile industry, application in the manufacture of paints and printing inks, it is used as a biological stain and it is the active ingredient in Gram's stain, veterinary medicine, and it is also employed as a bacteriostatic and dermatological agent in humans.[3] In addition, it is used as an additive to poultry feed to inhibit propagation of mould, intestinal parasites and fungus. The dye is responsible for causing moderate eye irritation, causing painful sensibility to light. It is highly toxic to mammalian cells and, if absorbed in harmful amounts through the skin, it can cause skin irritation and digestive tract irritation. In extreme cases it may also lead to respiratory and kidney failures, it is carcinogenic and it has been classified as a recalcitrant molecule since it is poorly metabolized by microbes.[4] Due to the structural complexity of the coloured compounds and their solubility in water, the degradation process is very difficult. Many alternative chemical and physical methods, such as coagulation/flocculation and ultrasonic treatment, have been employed, but most of these treatments are limited due to high operation costs, and the need for specialized equipment.[5]

Adsorption is an alternative process, with great perspective, for treatment of wastewater containing dyes and activated carbon is typically used; however, it is too expensive and requires regeneration which limits the usefulness of this method. Nowadays, it is important to find new lowcost and easily available adsorbents materials to be used in the treatment of wastewater containing organic compounds such as dyes. Several low-cost adsorbents have been investigated for the removal of crystal violet, including modified, $\mathrm{TiO}_{2}$-based nanosheet,[6] mesoporous aluminosilicates,[4] kaolin,[7] and bentonite,[8] among others.

\footnotetext{
*Corresponding author. Email: acolinc@uaemex.mx
} 
The surface of siliceous materials contains acidic silanol (among other surface groups) which causes a strong and often irreversible nonspecific adsorption. The vitreous tuff is related with other siliceous volcanic rocks, these rocks are named worldwide as volcanic glass and there are many types of these like perlite and obsidian, whose origins and physico-chemical characteristics are similar.[9] All these have high silica content, usually greater than $70 \%$ and are inexpensive and easily available in many countries. The leading producers of perlite (crude, processed) among Asian-European countries, for instance, are Greece, Japan, Turkey, and Hungary. About 70\% of the world's known perlite reserves are present along Aegean Coast in Turkey.[10] However, there are only a limited number of published papers on the use of perlite in the literature and the majority of these are about the use of expanded perlite-like adsorbent material. According to Qiangshan et al. [11] the expanded perlite is obtained by thermal treatment $(800$ $1100^{\circ} \mathrm{C}$ ) which makes to increase the porosity, decrease the original density and the volume is expanded up to 5-15 times to the original perlite but this procedure requires high temperature resulting in increased cost of production. In contrast, there are different deposits and manifestations of vitreous tuff located in countries that present volcanic origins, have different surface properties and have not studied to environmental applications.[12]

The vitreous tuff's main uses are directed to production of construction materials such as puzzolans, cements and concrete, soil improvement, laundry detergent, soil support and filling material.[13] For these reasons, the vitreous tuff has a little economic value but based upon its physical and chemical properties, it has high potentialities for treatment of liquid and gaseous waste, drinking water treatment and filtering of water for human consumption.[14] Its use like an adsorbent material would add major economic value, and most importantly provide a potentially inexpensive alternative to the existing of an adsorbent material superior to perlite according to surface properties and adsorption capacity.

In this work, based on the evaluation of geological and morphological characteristics of the adsorbent material, we evaluate the process of removal of crystal violet using vitreous tuff, through sorption kinetics and isotherms studies.

\section{Experimental}

\subsection{Adsorbate}

Crystal violet (C.I.: $42,555, \lambda_{\max }: 590 \mathrm{~nm}$, molecular wt.: $408 \mathrm{~g} / \mathrm{mol}$, and molecular formula: $\mathrm{C}_{25} \mathrm{H}_{30} \mathrm{~N}_{3} \mathrm{Cl}, 99 \%$ purity) was purchased from Hycel, Mexico. Dye solution was prepared by dissolving an appropriate amount of dye in distilled water. The concentrations of the samples were determined by using a standard calibration plot that showed a linear variation up to $500 \mathrm{mg} / \mathrm{L}$ concentration.

\subsection{Adsorbent material}

The vitreous tuff, obtained from The Magueyal deposit, Santiago de Cuba, Cuba, was milled and sieved. The grain size used in this work was minor to 60 mesh $(0.25 \mathrm{~mm})$ and a particle density of $0.61 \mathrm{~g} / \mathrm{cm}^{3}$. The material was used without any pretreatment for the removal of crystal violet from aqueous solutions in a batch process.

\subsection{Characterization}

\subsubsection{Scanning electron microscopy}

Scanning electron microscopy (SEM) observations of the vitreous tuff samples, before and after crystal violet adsorption, were carried out in a JEOL JSM 6510 microscope. The microanalysis was done with an energy X-ray dispersive spectroscopy (EDS) system.

\subsubsection{Chemical composition}

The mineralogical composition of the sample was determined by inductively coupled plasma-atomic emission spectrometry, using a Spectroflame FTMO8, Spectrophotometer.

\subsubsection{IR spectroscopy}

Infrared (IR) spectra in the $4000-400 \mathrm{~cm}^{-1}$ range with a resolution of $4 \mathrm{~cm}^{-1}$ and 32 scans sweep were recorded for the adsorbent, at room temperature, using a Bruker Tensor 27 FTIR attenuated total reflection (ATR). The sample did not require previous preparation due to the ATR attachment.

\subsubsection{Specific surface area BET ( $\left.S_{\mathrm{BET}}\right)$}

The textural properties evaluation was conducted using the technique of nitrogen physisorption at $77 \mathrm{~K}$ in a Quantachrome Autosorb-1. The specific surface area was determined by the equation of Brunnauer-Emmet-Teller (BET). The adsorption-desorption isotherms were obtained by plotting the adsorbed volume of nitrogen under standard conditions of temperature and pressure versus the relative pressure $P / P_{0}$ to determine the pore size and estimate the shape of the pores according to the International Union Pure Applied Chemistry (IUPAC) rules. The average pore diameter was determined with the method of Barrett, Joyner and Halenda and by the Kelvin equation.[15] The total pore volume was obtained at 0.99 relative pressures. The samples were previously degassed at $200^{\circ} \mathrm{C}$ for $3 \mathrm{~h}$, in order to remove water and $\mathrm{CO}_{2}$ from the environment which could be occluded inside the pores, and subsequently analysed.

\subsubsection{Zero charge point and concentrations of the acid-base groups}

The experiments were carried out with vitreous tuff and $0.01 \mathrm{M} \mathrm{NaCl}$ solutions, whose $\mathrm{pH}$ values were previously 
adjusted between 2 and 12, with intervals of 1 unit by adding $0.1 \mathrm{M} \mathrm{HCl}$ or $\mathrm{NaOH}$ solutions. After $24 \mathrm{~h}$ of contact, the samples were centrifuged, decanted, and $\mathrm{pH}$ was analysed in the final liquid phases with a Conductronic $\mathrm{pH}$ 120 equipment.

Determination of concentrations of the vitreous tuff acid-base groups was done as follows: for the superficial basicity, samples of $200 \mathrm{mg}$ of vitreous tuff were put in contact with $25 \mathrm{~mL}$ of $0.025 \mathrm{M} \mathrm{HCl}$ solution, using dark glass bottles, and shaken for $24 \mathrm{~h}$ at $120 \mathrm{rpm}$ and $303 \mathrm{~K}$. After that, the samples were decanted and the excess acid was titrated with $0.025 \mathrm{M} \mathrm{NaOH}$. The superficial acidity was obtained by a similar procedure, where a $0.025 \mathrm{M} \mathrm{NaOH}$ solution was put in contact with the vitreous tuff and the solution titration was performed using $0.025 \mathrm{M} \mathrm{HCl}$. The experiments were done in duplicate.

\subsection{Adsorption kinetics}

\subsubsection{Water adsorption kinetics}

This method was applied to measure the kinetic curves for water adsorption on vitreous tuff and to extract the apparent and pore diffusivities of water. Adsorption kinetics of water on vitreous tuff was studied at $298 \mathrm{~K}$. To carry out this experiment, the adsorbent $(2 \mathrm{~g})$ was placed in a vial, dried at $373 \mathrm{~K}$ for $8 \mathrm{~h}$ in a temperature-controlled oven, cooled to room temperature in a desiccator, and weighed to $\pm 0.1 \mathrm{mg}$ on an analytical balance (Digital Sartorius BS 124S). The sample was placed in a desiccator, into which a porcelain capsule containing water $(50 \mathrm{~mL})$ was also placed. The water uptake was determined by weighing the beaker containing the adsorbent at different times. This system was used to determine the adsorbed amount of water onto vitreous tuff. The amount of adsorbed water in a sample was calculated as a function of time.[16] The experimental data were analysed using Origin version 8.0 software.

\subsubsection{Crystal violet adsorption kinetics}

Kinetic removal of crystal violet by the vitreous tuff was performed as follows: samples of $500 \mathrm{mg}$ of the adsorbent and $25 \mathrm{~mL}$ aliquots of $0-432 \mathrm{mg} / \mathrm{L}$ solution were placed in dark glass bottles and shaken at different times $(4,6,8,10,20,30,40,50,60,70,80$, and $100 \mathrm{~min}$ ) at $120 \mathrm{rpm}$ (settling velocity in aqueous medium, $u_{t}=1.17 \mathrm{~cm} / \mathrm{s}$ and $N_{\mathrm{Re}}=10$ ) and $303 \mathrm{~K}$. After that, the samples were centrifuged and decanted. The experiments were performed in duplicate. The crystal violet dye concentrations in the solutions were determined using a UV/Vis Perking Elmer Lambda 10 ultravioletvisible spectrophotometer analyzer, with $\lambda=590 \mathrm{~nm}$. The $\mathrm{pH}$ of each solution was measured before and after the treatments.

\subsection{Adsorption isotherms}

About $500 \mathrm{mg}$ samples of vitreous tuff were put in contact with $25 \mathrm{~mL}$ of crystal violet solutions of different concentrations $(432-2849 \mathrm{mg} / \mathrm{L})$ for $2 \mathrm{~h}$, respectively, at $30^{\circ} \mathrm{C}$. Crystal violet concentrations were determined in the liquid phases as described above, and the $\mathrm{pH}$ was measured in each solution.

\section{Results and discussion}

\subsection{Characterization of the adsorbent}

\subsubsection{Geological characteristics}

There are appreciable quantities of the mineral selected in the region where it is located; the deposit has forecast resources in the order of three million cubic metres. It is constituted by glassy tuff of half acid composition. From the mineralogy point of view, it is made up of volcanic glass (vitreous phase) between $70-85 \%, 10-15 \%$ montmorillonite, and 3-5\% calcite. The vitreous tuff horizon is about $3-5 \mathrm{~m}$, these tuffs have beige-white colour, are light, abrasive to the touch, massive, and porous. The useful horizons are forming lithologically for vitroclastic tuffs, litovitroclastics, cristalovitroclastics with the insertion of calcareous tuffs, tuffaceous sandstones, and overlying packages of zeolitizeds tuffs. These rocks are part of Sabaneta lithostratigraphic formation, from Palaeocene-lower (Daniane top) to the Eocene-middle, Volcanic Island arc of the Palaeocene of Cuba' eastern.[13]

\subsubsection{Scanning electron microscopy}

SEM photographs in Figure 1(a) and 1(b) were taken at $1000 \times$ magnification to observe the superficial morphology of vitreous tuff before and after crystal violet adsorption, respectively. Figure 1(a) showed a rough texture material, with cavities of different dimensions and shapes, predominantly large and wide cavities, also with slits.

It is also observed that the presence of agglomerates in the form of tubular and laminar crystals could be the product of the transformation of amorphous material into clinoptilolite and mordenite zeolites type. This morphology of sedimentary characteristic is typical of clinoptilolite-rich tuffs, which occurred as euhedral plates and laths, crystals displaying characteristic monoclinic symmetry and many are coffin-shaped and cubic-like crystals.[17] The genesis of this type of occurrence is due to that volcanic glass is the real precursor of zeolites. It is also known that the mordenite is associated in nature with the clinoptilolite mainly.[18] In Cuba, the zeolitization predominates as regional phenomenon, given the deposition environment of the rocks. Furthermore, the zeolites reported in Cuba as product of volcanic glass alteration of tuffs are mainly clinoptilolite and mordenite, which are rich in $\mathrm{SiO}_{2}$.[12]

Vitreous tuff saturated with crystal violet is shown in Figure 1(b), the morphologies are similar to the original 

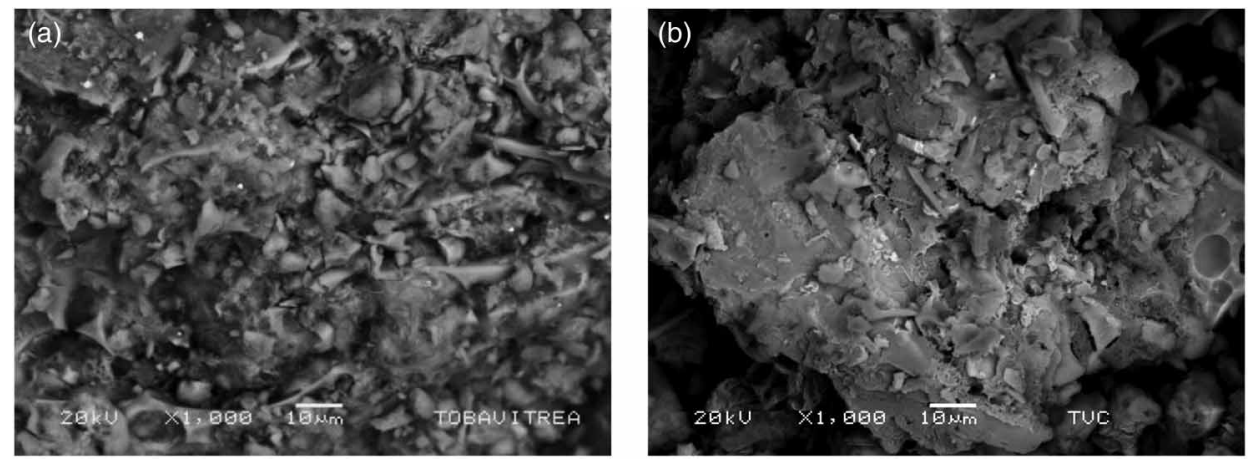

Figure 1. Scanning electron micrographs of vitreous tuff $1000 \times$ (a) before $1000 \times$ and (b) after crystal violet adsorption.

Table 1. EDS analisys before and after crystal violet (CV) adsorption on vitreous tuff.

\begin{tabular}{lcc}
\hline Elements & $\begin{array}{c}\text { Weight percentage } \\
\text { vitreous tuff }\end{array}$ & $\begin{array}{c}\text { Weight percentage } \\
\text { CV-vitreous tuff }\end{array}$ \\
\hline $\mathrm{C}$ & - & 25.08 \\
$\mathrm{O}$ & 44.7 & 39.16 \\
$\mathrm{Na}$ & 0.54 & 0.40 \\
$\mathrm{Mg}$ & 1.21 & 1.00 \\
$\mathrm{Ca}$ & 1.73 & 0.54 \\
$\mathrm{Si}$ & 38.57 & 24.82 \\
$\mathrm{~K}$ & 2.18 & 1.14 \\
$\mathrm{Al}$ & 7.66 & 5.40 \\
$\mathrm{Fe}$ & 3.42 & 2.46 \\
\hline
\end{tabular}

material and the dye was deposited on the surface on vitreous tuff indicating slight rougher surface. The presence of large cavities corresponding to mesopores suggests that dye molecules can be embedded on the adsorbent surface. It is probable that the crystal violet molecule penetrates and interacts with surface groups of the mineral.[19]

The elemental composition of the vitreous tuff, before and after crystal violet, is presented in Table 1 . The main elements, such as $\mathrm{Si}, \mathrm{Al}$, and $\mathrm{O}$, corresponding to aluminosilicates were identified. The quantity of $\mathrm{Ca}$ and $\mathrm{K}$ in the vitreous tuff notably decreased when the samples were in contact with the crystal violet solutions, which suggests that $\mathrm{Ca}^{2+}$ and $\mathrm{K}^{+}$play a role in the adsorption process. After adsorption, carbon was found in the vitreous tuff.

\subsubsection{Chemical composition}

Chemical analysis exhibits the multicomponent character of mineral. The presence of $\mathrm{SiO}_{2}$ and $\mathrm{Al}_{2} \mathrm{O}_{3}$ in vitreous tuff constitutes almost $80 \%$ of the mineral composition, besides iron and alkaline and alkaline-earth elements but to a lesser extent. The chemical composition of vitreous tuff is similar to mordenite and volcanic glass from Ají de la Caldera deposits and similar to Palmarito del Cauto (ZPC) zeolitic deposits, located just $6 \mathrm{~km}$ away in the same locality. The horizon of ZPC zeolite consists of a cycle of sedimentation, which is closed by the tuffs, composed almost of mordenite exclusively.[12] The approach is confirmed by the fact that the volcanic glass is a prezeolitic material, from which under certain hydrothermal conditions the zeolites are forming. The volcanic glass of Ají de la Caldera deposits is located in another province of vitreous tuff (Guantánamo), both located in the eastern region of the country and it is hoped that their geological origin could be very similar, hence the similarity of their chemical composition.[20]

\subsubsection{IR analysis}

The IR spectrum of vitreous tuff displays a number of absorption peaks mainly composed of $\mathrm{Si}-\mathrm{O}(\mathrm{H})-\mathrm{Si}$, Si$\mathrm{O}(\mathrm{H})-\mathrm{Al}, \mathrm{Si}-\mathrm{O}-\mathrm{Si}$, and $\mathrm{Si}-\mathrm{O}-\mathrm{Al}$ groups, which is consistent with the peaks in the $3000-3700 \mathrm{~cm}^{-1}$ region and a peak at $3606 \mathrm{~cm}^{-1}$ attributed to hydroxyl groups of water $(\mathrm{O}-\mathrm{H})$, coordinated to interlayer cations or as coordination occurs with some cations on clay surfaces.[21] The band near $1630 \mathrm{~cm}^{-1}$ is due to the water of crystallization bending vibration, and the band near $784 \mathrm{~cm}^{-1}$ corresponds to $-\mathrm{OH}$ translation. The $\mathrm{Si}-\mathrm{O}-\mathrm{Si}$ stretching vibration appears near $1010 \mathrm{~cm}^{-1}$ as a strong band. The absorption peaks at 514 and $422 \mathrm{~cm}^{-1}$ are associated with $\mathrm{O}-\mathrm{Si}-\mathrm{O}$ bends of glassy volcanic rock.[22]

\subsubsection{Surface area, BET $\left(S_{B E T}\right)$, and pore size distribution}

The adsorption-desorption nitrogen isotherm for the vitreous tuff is shown in Figure 2. Generally, the pore geometry (shape) is a parameter that greatly affects the shape of adsorption isotherm as well as the presence or absence of hysteresis loop. Hence, it is the important to identify the type of isotherm for the vitreous tuff material.

With respect to the isotherm, the IUPAC classifies it according to six types. Comparing the experimental isotherm obtained with the typical forms published in the literature,[23] it allows to conclude that this is of type IV of the IUPAC classification and that the shape of hysteresis loop corresponds to a $\mathrm{H} 3$ type hysteresis. According to the literature, the $\mathrm{H} 1, \mathrm{H} 2$, and $\mathrm{H} 3$ hysteresis types and the II and 


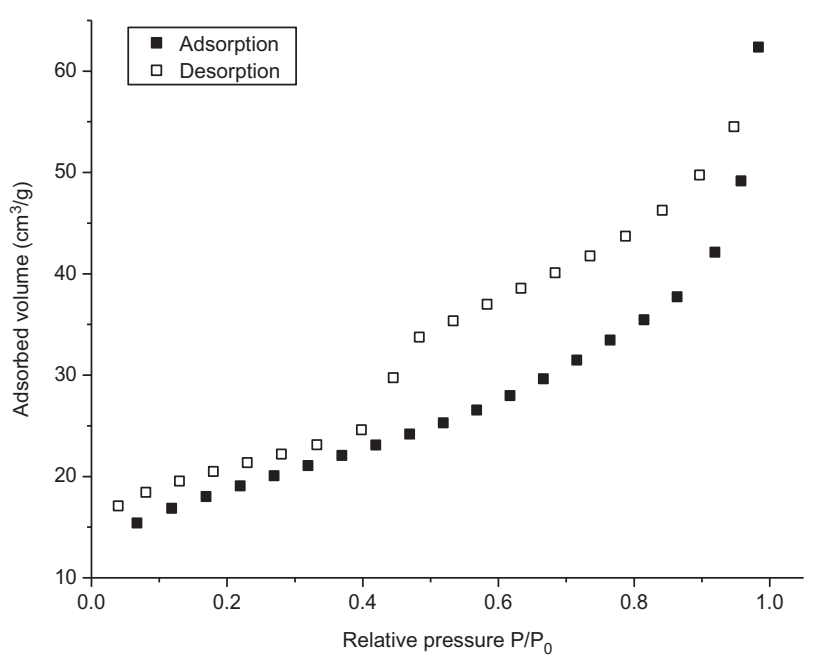

Figure 2. Adsorption-desorption of $\mathrm{N}_{2}$ on vitreous tuff.

IV types of isotherms are mesoporous solids characteristics. It was concluded that the vitreous tuff is essentially mesoporous according to the pores classification established by the IUPAC, associated generally with solids constituted by aggregates or agglomerates of particles in the form of a sheet or parallel plate with non-uniform size.[15] A similar result was provided with nitrogen adsorption on silica spherules and alumina spherules compacted at a series of pressures and demonstrate the presence of mesopores brings about an increase in adsorption.[24]

The shape and pores size, the material specific surface area $\left(S_{\mathrm{e}}\right)$, and the average size pore distribution in the material were obtained from the experimental data of adsorption-desorption isotherm. In applying the BET model to the experimental data, the surface area of the vitreous tuff material $\left(S_{\mathrm{e}}=64.40 \mathrm{~m}^{2} / \mathrm{g}=3.9 \times 10^{-5} \mathrm{~m}^{2} / \mathrm{m}^{3}\right)$ was obtained.

The value of the specific surface area might seem small compared with those of other adsorbents such as activated carbon, but specifically for the vitreous tuff was high. For instance, Blanco et al. [25] obtained an activated carbon from palm seed (Veitchia Merriillii) with a specific surface value of $337 \mathrm{~m}^{2} / \mathrm{g}$. Wang and Zhu [26] modified a commercial-activated carbon (Calgon, USA) by acid treatment to remove crystal violet initiating with a specific surface area of $972 \mathrm{~m}^{2} / \mathrm{g}$ which, after treatment, increased to $1015 \mathrm{~m}^{2} / \mathrm{g}$. However, the value of this parameter reported for tuff (volcanic glass) in Turkey was $1.22 \mathrm{~m}^{2} / \mathrm{g}$ [27] and the Cuban volcanic glass from Ají de la Caldera deposits (VVAC) presented a value of $32 \mathrm{~m}^{2} /$ g. [12] The vitreous tuff $S_{\mathrm{e}}$ value was 52 times higher compared with the first (Turkey) and twice higher than that of VVAC, so comparatively the specific surface of vitreous tuff is very large.[10]

The total pore volume was $0.16 \mathrm{~cm}^{3} / \mathrm{g}$, and the mean pore diameter was $25 \AA$. The average pore size distribution revealed mainly the presence of mesopores, but closely to micropores, which agreed with the result obtained from the interpretation of adsorption-desorption isotherm and the hysteresis loop. In this regard, the vitreous tuff material presented lower porosity than VVAC; therefore, the specific surface value was greater.

\subsubsection{Zero charge point determination}

The $\mathrm{pH}_{\mathrm{eq}}$ values for the sets of experiments with vitreous tuff- $\mathrm{NaCl}$ solution (figure not shown) showed a notorious buffer effect; for $6<\mathrm{pH}_{\text {initial }}<9, \mathrm{pH}_{\mathrm{eq}}=7.1 \pm 0.1$. The zero charge point of vitreous tuff was determined when the $\mathrm{pH}_{\mathrm{eq}}$ was equal or quite similar to the $\mathrm{pH}_{\text {initial }}$.

The electrical charge at the oxide surface/aqueous phase to protonation/deprotonation of the surface can be ascribed as

$$
\begin{aligned}
-\mathrm{SOH}+\mathrm{H}^{+} & \rightleftharpoons \mathrm{SO} \mathrm{H}_{2}^{+} \\
-\mathrm{SOH}+\mathrm{OH}^{-} & \rightleftharpoons \mathrm{SO}^{-}+\mathrm{H}_{2} \mathrm{O} .
\end{aligned}
$$

And at isoelectric point

$$
\left[-\mathrm{SO} \mathrm{H}_{2}^{+}\right]+\mathrm{H}^{+}=\left[\mathrm{SO}^{-}\right] .
$$

The $\mathrm{pHz}$ indicates that at this point, there is no charge at the surface, that is, the total positive charges are equal to the total negative charges.[27]

Silber et al. [28] studied two samples of perlite, a glassy volcanic rock with a chemical composition similar to vitreous tuff $\left(\mathrm{SiO}_{2}, 71-75 \% ; \mathrm{Al}_{2} \mathrm{O}_{3}, 12-18 \% ; \mathrm{K}_{2} \mathrm{O}, 4-5 \%\right.$; $\mathrm{Na}_{2} \mathrm{O}, 3-4 \%$; $\mathrm{CaO}, 0.5-2 \%$; and $\mathrm{MgO}, 0.1-0.5 \%$ ), and found $\mathrm{pH}_{\mathrm{eq}}=3-8$, in accord with previous reports, since that perlite was negatively charged from dissociation of hydroxyl groups, which is typical of oxides surfaces.

The total surface acidity and basicity of vitreous tuff were 164 and $140 \mathrm{meq} / \mathrm{g}$, respectively. Similar results between acidity and basicity at vitreous tuff could be attributed to amphoteric character of surface active sites, which may correspond to groups identified by IR techniques. In general, there is a smaller increase in acid groups than in basic groups on the surface of vitreous tuff, which provides a net positive charge. Furthermore, the $\mathrm{pH}$ of the solution after adsorption decreased initial $\mathrm{pH}$ from 6.0-6.5 to 3.0-5.0. The $\mathrm{pH}_{\mathrm{s}}$ of the initial solutions are affected in the adsorption process by acid surface charge of the adsorbent. Between solution $\mathrm{pH} 3.0-5.0$, dye is negative charged $(\mathrm{p} K \mathrm{a}=1.0)$ and the surface is positive charge on the surface of the adsorbent, could be increased crystal violet adsorption on active site.

These results are also consistent with the work by Monash and Pugazhenthi [4] who reported the crystal violet removal using mesoporous aluminosilicates materials, and found that the $\mathrm{OH}$ groups act as centres for adsorption through forming hydrogen bonds with the adsorbate and could be divided into: isolated free silanol $(-\mathrm{SiOH})$, germinal-free silanol $\left(-\mathrm{Si}(\mathrm{OH})_{2}\right)$, and vicinal or bridged or 

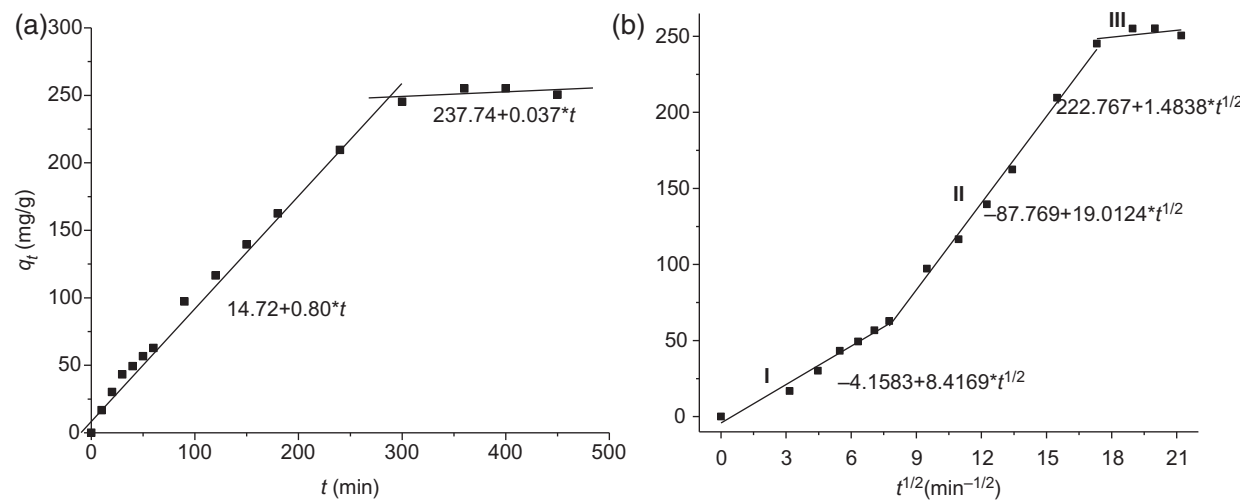

Figure 3. (a) Kinetics water adsorption on vitreous tuff and (b) intraparticle-diffusion plots for water adsorption in vitreous tuff. I Film diffusion, II intraparticle diffusion, and III binding on active sites.

$\mathrm{OH}$ groups bound through the hydrogen bond, and these groups are responsible of dye adsorption by the $n-\pi$ interaction mechanism and electrostatic attraction between the dye and the surface of the adsorbents. Therefore, the chemical composition and the acid-base groups' concentrations of the adsorbents play an important role in the adsorption of dyes.

\subsection{Adsorption kinetic}

\subsubsection{Water adsorption kinetic}

The adsorption kinetics, as expressed in terms of the rate of uptake of solute (which governs the residence time), is one of the important considerations for economical wastewater treatment applications.[28] The water adsorption kinetics of the vitreous tuff sample is shown in Figure 3(a), the equilibrium was $300 \mathrm{~min}$ at $30-40 \%$ relative humidity. In order to elucidate the adsorption mechanism and potential rate-controlling step, four kinetic models, including the pseudo-first-order, the pseudo-second-order, Elovich, and the diffusion model were analysed.

The pseudo-first-order model (Lagergren): In this model, which is commonly used for homogeneous sorbents and physical sorption, the sorption rate is proportional to the solute concentration. If the sorption behaviour is pseudofirst-order, then the experimental results could be adjusted to the following equation:

$$
q_{t}=q_{\mathrm{e}}\left(1-e^{K_{\mathrm{L}} t}\right)
$$

where $q_{\mathrm{e}}$ and $q_{t}$ are the amounts of dye adsorbed (mg/g) in the equilibrium and at time $t(\mathrm{~min})$, respectively, and $K_{\mathrm{L}}$ $\left(\mathrm{min}^{-1}\right)$ is the adsorption constant of Lagergren.[29]

The second-order model (Elovich): This model has been used suitably in chemisorptions on highly heterogeneous materials [29] and is represented by the following equation:

$$
q_{t}=\frac{1}{b}(1-a b t)
$$

where $q_{t}$ is the amount of adsorbed dye at time $t, a$ is the sorption constant of the dye $(\mathrm{mg} / \mathrm{g})$, and $b$ is the desorption constant $(\mathrm{mg} / \mathrm{g})$. The equation considers that the sorption sites have different energies on the surface of the adsorbent, perhaps the experimental data could be adjusted to this model for this reason.

The pseudo-second-order model: The pseudo-secondorder model is based on the assumption that the ratelimiting step may be chemisorption, involving valence forces through the sharing or exchange of electrons between adsorbent and adsorbate.[29] This model can be represented in the following equation:

$$
q_{t}=\frac{q_{\mathrm{e}}^{2} k t}{1+q_{\mathrm{e}} k t},
$$

where $q_{t}$ and $q_{\mathrm{e}}$ are the amounts adsorbed at time $t$ and at equilibrium $(\mathrm{mg} / \mathrm{g})$, respectively, and $k$ is the pseudo-second-order rate constant for the sorption process (g/mg.min).

Diffusion model: The experimental data of dye adsorption were analysed assuming a three-step model: (1) external mass transfer of dye ions from bulk solution to the adsorbent particle surface, (2) intraparticle diffusion, and (3) adsorption at internal sites. In general, step (3) is considered rapid compared with the first two steps therefore it cannot be said to be the rate-controlling step. Consequently, the two rate-limiting steps considered are external mass transfer and intraparticle diffusion. The rate of adsorption is usually determined by the change in concentration of adsorbate with the adsorbent as a function of time [3] and the amount adsorbed per unit weight of adsorbent $\left(q_{t}\right)$ versus $t^{0.5}$, respectively; the observed multilinearity in the plots reveals the different stages in adsorption.

The change in concentration of dye with respect to time $t=0, C_{\mathrm{e}}=0$ can be expressed by

$$
-\frac{\mathrm{d} C}{\mathrm{~d} t}=k_{s} S\left(C_{t}-C_{\mathrm{e}}\right),
$$

where $k_{s}$ is the external mass transfer coefficient $(\mathrm{m} / \mathrm{min})$, and $S$ is the surface area of the adsorbent per unit volume of 
the particle slurry $\left(\mathrm{m}^{2} / \mathrm{m}^{3}\right)$. In our case, $S$ was experimentally determined by the BET surface area measurement.

The external mass transfer coefficient $k_{s}$ was calculated from the slope of $C_{t} / C_{0}$ versus time $t$ using the experimental kinetic data for the first initial rapid process $(0-20 \mathrm{~min})$.[9]

The intraparticle-diffusion constant (internal surface and pore diffusion) can be calculated by the following equation [3]:

$$
q_{t}=k_{d} t^{0.5}+C,
$$

where $q_{t}$ is the fraction dye uptake $(\mathrm{mg} / \mathrm{g})$ at time $t, k_{d}$ $\left(\mathrm{mg} / \mathrm{g} \cdot \mathrm{min}^{0.5}\right)$ is the intraparticle-diffusion rate constant determined from the slope of the plot $q_{t}$ versus $t^{0.5}$, and $C$ is the intercept of the line $(\mathrm{mg} / \mathrm{g})$ which is proportional to the boundary layer thickness. The contribution of intraparticle-diffusion mechanism to the adsorption process can be further investigated by calculation of the diffusion coefficient in the solid; $D_{w}\left(\mathrm{~m}^{2} / \mathrm{min}\right)$, which is related to $k_{d}$ by the relation [30]

$$
k_{d}=\left(\frac{12 q_{\mathrm{e}}}{d_{\mathrm{p}}}\right)\left(\frac{D_{w}}{\pi}\right)^{0.5},
$$

where $d_{\mathrm{p}}$ is the particle size diameter (m) and $q_{\mathrm{e}}$ is adsorption capacity at equilibrium.

Upon comparison among the kinetic models, the pseudo-first-order model yielded the best results for water, this result indicates physisorption between the water molecule and the surface of the adsorbent by hydrogen bonding. Table 2 shows that acceptable adjustment of data was also obtained by using the other two models (secondorder and pseudo-second-order), these models presented slight deviations and correlation coefficients were lower than that obtained using the pseudo-first-order equation using the Origin 8.0 program.

Table 2. Kinetic parameters of the water and crystal violet (CV) adsorption by vitreous tuff.

\begin{tabular}{lcc}
\hline Kinetics models & $\mathrm{H}_{2} \mathrm{O}$ & $\mathrm{VC}$ \\
\hline Pseudo-first-order & & \\
$q_{t}(\mathrm{mg} / \mathrm{g})$ & 316.12 & 82.06 \\
$K_{\mathrm{L}}\left(\mathrm{min}^{-1}\right)$ & 0.004 & 1.08 \\
$R^{2}$ & 0.9907 & 0.9906 \\
Pseudo-second-order & & \\
$q_{t}(\mathrm{mg} / \mathrm{g})$ & 477.25 & 83.47 \\
$K(\mathrm{~g} / \mathrm{mg} \cdot \mathrm{min})$ & $6.15 \cdot 10^{-6}$ & 0.04 \\
$R^{2}$ & 0.9883 & 0.9975 \\
Second-order & & \\
$a(\mathrm{mg} / \mathrm{g})$ & 1.5 & $2.2 \cdot 10^{14}$ \\
$b(\mathrm{mg} / \mathrm{g})$ & 0.005 & 0.43 \\
$R^{2}$ & 0.9859 & 0.9977 \\
Intraparticle diffusion & & \\
$K_{d}\left(\mathrm{mg} / \mathrm{g} \cdot \mathrm{min}^{0.5}\right)$ & 19.01 & 0.53 \\
$C$ & 87.76 & 78.8 \\
$R^{2}$ & 0.9939 & 0.696 \\
\hline
\end{tabular}

Note: RSS, residual sum of square.
Since the models above mentioned cannot identify a diffusion mechanism, the external mass transfer and intraparticle-diffusion models were also tested to find the rate-controlling step. Figure 3(b) illustrates the diffusion process for adsorption of water onto vitreous tuff. It is observed that there are three linear portions which elucidate the three adsorption stages: external mass transfer at initial period followed by intraparticle diffusion and then adsorption at internal sites onto vitreous tuff. The slope and $R^{2}(0.9939)$ of the second linear portion suggest that the intraparticle-diffusion model describes the adsorption of water on vitreous tuff better. However, the $C$ intercept does not pass through the origin; therefore, this indicates that intraparticle diffusion is involved in the sorption process, it is not the only rate-limiting mechanism and that some other mechanisms can be involved. The diffusion coefficient in the solid $\left(D_{w}\right)$ was $7.88 \times 10^{-12} \mathrm{~m}^{2} / \mathrm{min}$, the obtained value in this study is lower than Streptomyces rimosus biomass treated with $\mathrm{NaOH}\left(10^{-9} \mathrm{~m}^{2} / \mathrm{s}\right.$ or $\left.6 \times 10^{-8} \mathrm{~m}^{2} / \mathrm{min}\right)$ for water kinetic adsorption.[31]

The behaviour of water in the porous materials indicated that water settles on the surface of a solid first as a monolayer and with increasing moisture as multilayers. The first layer is hydrogen bonded to the surface of the solid and is immobile. Additional layers can behave as a liquid moving along the surface of the sample and even causing dissolution of the solid. Alternatively, Collins et al. [32] found that the $\mathrm{H}_{2} \mathrm{O}$ surface concentrations, obtained from the plateau data of individual kinetic adsorption isotherms at $43 \%$ and $51 \%$ relative humidity, show that a complete monolayer is formed with negligible second-layer adsorption at the above-mentioned relative humidity and at $85 \%$ relative humidity. The initial rapid rise water adsorption continues with only a slight change of curvature in the region that may relate to a slowing down of the adsorption, suggesting the possible presence of additional adsorbate structures or, perhaps, simply a balance condition between adsorption and desorption rates at this relative humidity. Also, it suggests that when the silica surfaces are dried and then exposed to water vapour, water molecules adsorb onto the surface, presumably by direct interaction with the silanols through hydrogen bonding. Other possibility is due to the presence of various silanol type sites on the adsorbent surface interacting with water molecules. Another option is related to configurations feasible of interaction: (a) 1:1 attachment of one $\mathrm{H}_{2} \mathrm{O}$ molecule on a single silanol group or (b) 1:2 attachment of one $\mathrm{H}_{2} \mathrm{O}$ molecule and two silanol groups. Most of the relevant literature suggests that the initial $\mathrm{H}_{2} \mathrm{O}$ adsorption takes place with a 1:2 stoichiometry.

\subsubsection{Crystal violet adsorption kinetics}

The experimental results showed in Figure 4(a) were fitted to pseudo-first-order (Lagergren), second-order (Elovich) and pseudo-second-order kinetic models, applying a nonlinear regression analysis. According to Figure 4(a), a rapid 
(a)

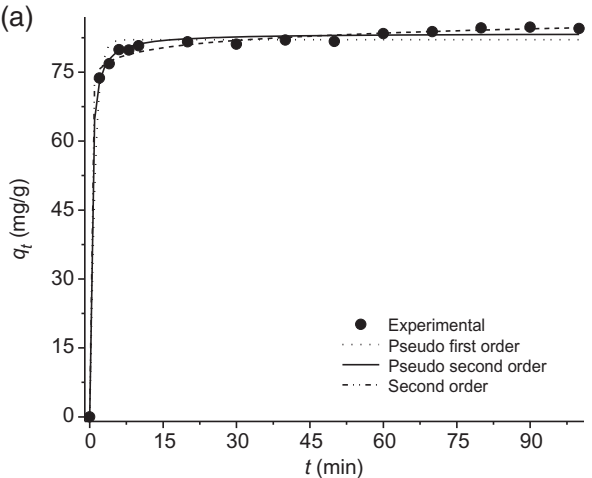

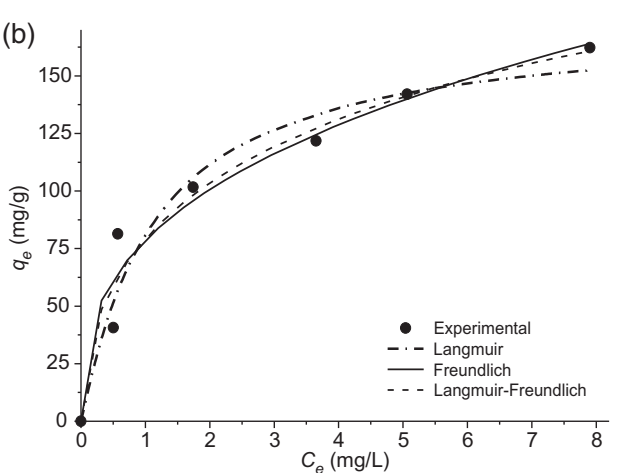

Figure 4. (a) Adsorption kinetics of crystal violet by vitreous tuff and (b) comparison between the measured and modelled isotherms profiles for the adsorption of crystal violet onto vitreous tuff.

increase in the adsorption of crystal violet can be observed, the equilibrium was reached in $20 \mathrm{~min}$, and the maximum adsorption of crystal violet was $81 \mathrm{mg} / \mathrm{g}$; after $30 \mathrm{~min}$, the adsorbed amount of crystal violet was constant, indicating that the equilibrium was reached. The equilibrium $\mathrm{pH}$ decreased immediately to 3.2 .

The values of constants of kinetic models obtained from the plots for adsorption of crystal violet on to vitreous tuff are shown in Table 2. The data showed good agreement with pseudo-first-order, pseudo-second-order and Elovich kinetic models $\left(R^{2}>0.9900\right)$. The best correlation for the system provided by the second-order model $\left(R^{2}>0.9977\right)$ suggests that chemical sorption involving valence forces through sharing or exchange of electrons between the adsorbent and adsorbate might be significant.

The results of second-order model were observed and found that the sorption constant: ' $a$ ' was $2.2 \times 10^{14}$ times higher than the desorption constant to crystal violet adsorption onto vitreous tuff, this behaviour may indicate that the dye is most stable in adsorbent and then chemical adsorption indicates that the adsorption process is irreversible. The rate of adsorption of crystal violet on kaolin clay followed the pseudo-second-order.[7]

In general, the adsorption process involves multistep, mainly the external mass transfer followed by the intraparticle diffusion (Figure 5). The external mass transfer coefficient $k_{s}$, calculated from Equation (6) for crystal violet adsorption onto vitreous tuff was $17.9 \mathrm{~m} / \mathrm{min}\left(R^{2}=0.943\right)$ (figure not shown). Meanwhile, the intraparticle-diffusion coefficient $k_{d}$ (Table 3) was calculated from the slope of the corresponding linear region II of Figure 5. The value of $k_{d}$ was $0.53 \mathrm{mg} / \mathrm{g} \mathrm{min}^{0.5}$ and intercept was $78.80 \mathrm{mg} / \mathrm{g}$ $\left(R^{2}=0.693\right)$.

Intraparticle-diffusion model shows that $D_{w}$ coefficient value is higher for water kinetic adsorption experiments $\left(7.88 \times 10^{-12} \mathrm{~m}^{2} / \mathrm{min}\right)$ than for the crystal violet $(5.55 \times$ $10^{-14} \mathrm{~m}^{2} / \mathrm{min}$ ) indicating that water adsorbed faster than crystal violet onto vitreous tuff. This value is lower than jute fibre carbon $\left(7.32 \times 10^{-9} \mathrm{~m}^{2} / \mathrm{min}\right)$ for crystal violet adsorption [33]; this was attributed to the size particle of the present system.

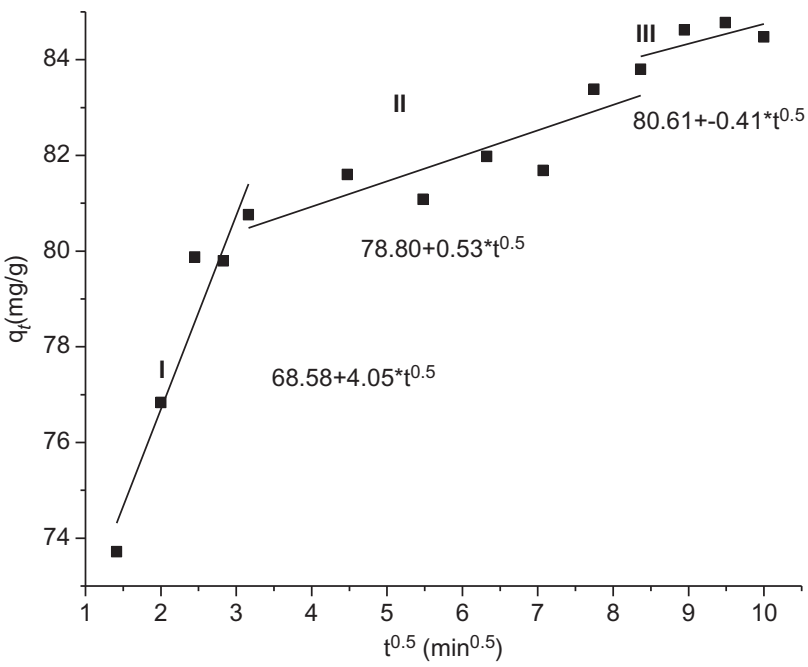

Figure 5. Intraparticle-diffusion plots for crystal violet adsorption in vitreous tuff.

Based on the obtained results from the analysis of the diffusion kinetic adsorption data, it can be suggested that the external mass transfer diffusion is the rate-controlling step. The agitation speed, initial dye concentration, adsorbent mass and particle size can be the important variables in adsorption phenomena that influence the distribution of the solute in the bulk solution and the formation of the external boundary film.[34]

Finally, the obtained results of all kinetic models can also be used to determine the equilibrium time and the rate of adsorption and can be used to develop predictive models for column experiments.

\subsection{Adsorption isotherms}

The adsorption isotherm represents the relationship between Sthe concentration of the solute in the adsorbent $q_{\mathrm{e}}$ $(\mathrm{mg} / \mathrm{g})$ and in the solution at equilibrium $C_{\mathrm{e}}(\mathrm{mg} / \mathrm{L})$. The experimental results were analysed by using the Langmuir, Freundlich and Langmuir-Freundlich adsorption models in 
Table 3. Adsorption isotherm parameters of crystal violet by vitreous tuff.

\begin{tabular}{|c|c|c|c|c|c|c|c|c|c|}
\hline \multicolumn{10}{|c|}{ Adsorption isotherms } \\
\hline \multicolumn{3}{|c|}{ Langmuir } & \multicolumn{3}{|c|}{ Freundlich } & \multicolumn{4}{|c|}{ Langmuir-Freundlich } \\
\hline$q_{\max }(\mathrm{mg} / \mathrm{g})$ & $b(\mathrm{~L} / \mathrm{mg})$ & $R^{2}$ & $K_{\mathrm{F}}(\mathrm{mg} / \mathrm{L})$ & $1 / n$ & $R^{2}$ & $K(\mathrm{mg} / \mathrm{g})$ & $a(\mathrm{~L} / \mathrm{mg})$ & $1 / n$ & $R^{2}$ \\
\hline 174.01 & 0.89 & 0.9433 & 78.66 & 0.35 & 0.9528 & 103.79 & 0.31 & 0.66 & 0.9434 \\
\hline
\end{tabular}

order to determine the correlation between solid phase and aqueous concentrations at equilibrium.

The Langmuir adsorption isotherm is

$$
q_{\mathrm{e}}=\frac{q_{\mathrm{max}} b C_{\mathrm{e}}}{1+b C_{\mathrm{e}}}
$$

where $q_{\mathrm{e}}$ is the amount of dye adsorbed per unit weight of adsorbent $(\mathrm{mg} / \mathrm{g}), q_{\max }$ is the amount of dye adsorbed per unit weight of adsorbent in forming a complete monolayer on the surface $(\mathrm{mg} / \mathrm{g}), C_{\mathrm{e}}$ is the concentration of the dye in the solution at equilibrium ( $\mathrm{mg} / \mathrm{L})$, and $b$ is the constant related to the energy or net enthalpy of adsorption.[29] Fundamental characteristics of the Langmuir isotherm can be expressed by dimensionless separation factor, $R_{\mathrm{L}}$, defined by

$$
R_{\mathrm{L}}=\frac{1}{1+b C_{0}},
$$

where $C_{0}(\mathrm{mg} / \mathrm{L})$ is the highest initial concentration of adsorbate and $b(\mathrm{~L} / \mathrm{mg})$ is the Langmuir constant. The $R_{\mathrm{L}}$ parameter indicates the shape of the isotherm as follows: $R_{\mathrm{L}}>1$, unfavourable; $R_{\mathrm{L}}=1$, linear; $0<R_{\mathrm{L}}<1$, favourable; and $R_{\mathrm{L}}=0$, irreversible.[2]

The Freundlich equation is:

The mathematical representation of this model is

$$
q_{\mathrm{e}}=K_{\mathrm{F}} C_{\mathrm{e}}^{1 / n},
$$

where $q_{\mathrm{e}}$ is the amount of dye adsorbed per unit weight of adsorbent $(\mathrm{mg} / \mathrm{g}), C_{\mathrm{e}}$ is the equilibrium concentration of the dye in the solution $(\mathrm{mg} / \mathrm{L}), K_{\mathrm{F}}$ is the equilibrium constant indicative of adsorption capacity, and $n$ is the adsorption equilibrium constant whose reciprocal is indicative of the heterogeneity of surface sorbent.

This model assumes surface heterogeneity and exponential distribution of active sites and provides an empirical relationship between the adsorption capacity and equilibrium constant of the adsorbent.[29]

The Langmuir-Freundlich equation is: This model is a combination of both Langmuir and Freundlich models and it can be expressed by the following equation [29]:

$$
q_{\mathrm{e}}=\frac{K C_{\mathrm{e}}^{1 / n}}{\left(1+a \mathrm{C}_{\mathrm{e}}^{1 / n}\right)},
$$

where $q_{\mathrm{e}}$ is the amount of crystal violet per unit weight of adsorbent $(\mathrm{mg} / \mathrm{g}), C_{\mathrm{e}}$ is the equilibrium concentration of dye in solution (mg/L), and $K$ and $a$ are empirical constants. The model parameters were evaluated using Origin 8.0 software.

The results are shown in Table 3 and the modelled isotherms are plotted in Figure 4(b).

The maximum adsorption capacity obtained from the Langmuir isotherm was $174.01 \mathrm{mg} / \mathrm{g}\left(R^{2}=0.9433\right)$ although the correlation was good, it was not the best using this model. The dimensionless separation factor, $R_{\mathrm{L}}$ value for the adsorption of crystal violet onto vitreous tuff was $3.4 \times 10^{-4}$, indicating that the adsorption was a favourable process.

From both, Figure 4(b) and the regression coefficients (Table 3) it is found that the fit is better with the Freundlich than with the Langmuir and Langmuir-Freundlich models.

According to the nature of adsorbent, it is better to apply the Freundlich model to the results than the Langmuir model because it is a heterogeneous material. Therefore, the adsorption of crystal violet onto vitreous tuff occurred in a heterogeneous surface, the magnitude of $1 / n$ gives a measure of the favouring of adsorption. The values of $1 / n$ less than 1 represent a favourable adsorption. For the present study, the value of $1 / n$ also exhibited the same trend, representing a beneficial adsorption. The Langmuir-Freundlich model isotherm gave similar correlations than the Langmuir model.

\subsection{Adsorption mechanism}

Considering that the kinetic results obtained with the vitreous tuff were best fitted to the second-order model and the isotherms to the Freundlich model, it can be suggested that the adsorption mechanism of the dye is chemisorption on a heterogeneous material.

Taking into account the results of total surface acidity and basicity, the major acidity of the surface makes more probable the adsorption of a basics dye, such as crystal violet. The interaction of the molecules of crystal violet and the vitreous tuff surface can occur between the free-electron pair of the oxygen of the surface group and the delocalized $\pi$ electrons present in the aromatic rings of the dye molecule, as depicted in Figure 6.

The crystal violet molecule can produce the resonance and the $n-\pi$ interaction of the dye has an important effect on the sorption of crystal violet on the vitreous tuff.[4] Another possible interaction mechanism of the dye with the vitreous tuff is that $\mathrm{pH}$ of the dye solution is an important 


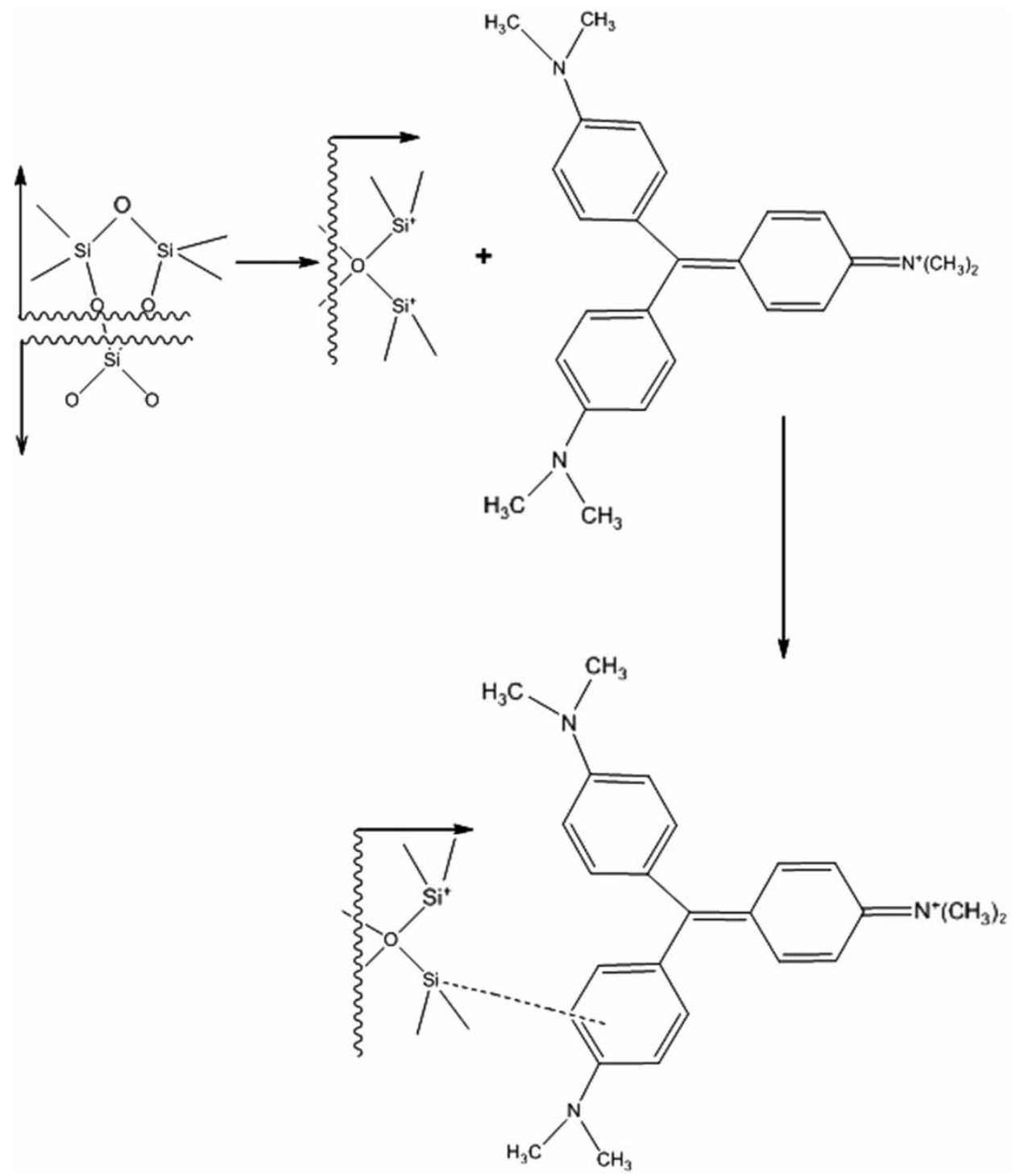

Figure 6. Adsorption mechanism of crystal violet on vitreous tuff.

parameter that controls the adsorption process, after adsorption the $\mathrm{pH}$ diminished (acid medium). Trgo and Periæ [35] showed that the amphoteric nature of hydroxyl surface groups $[=(\mathrm{Al} / \mathrm{Si})-\mathrm{OH}]$ can lead to the formation of sites with different energies, such that this mechanical effect increases the number of possible adsorption locations.

\subsection{Designing batch adsorption from isotherm data}

The effect of volume of solution to the adsorbent mass ratio $(\mathrm{V} / \mathrm{M})$ on the dye adsorption process at different initial concentrations is an important factor to be considered in the adsorber design.[36] In this case, V/M ratios have been obtained using the experimental isotherm data of crystal violet on vitreous tuff.

Adsorption isotherms can be used to predict the design of single-stage batch adsorption systems, in this case the effluent contains a volume fixed (L) of water with an initial crystal violet concentration $\left(C_{0}=432 \mathrm{mg} / \mathrm{L}\right)$, which is to be reduced to $C_{f}(\mathrm{mg} / \mathrm{L})$ in the adsorption process to obtain a $90 \%$ of dye removal. In the treatment stage $L_{s}$ gram of Vitreous tuff is added to solution and the dye concentration on the solid change from $Q_{0}=0 \mathrm{mg} / \mathrm{g}$ (initially) to $Q_{\mathrm{e}}$ $(\mathrm{mg} / \mathrm{g})$. Through mass balance we can calculate the amount of dose need for the required percentage removal of dye from aqueous solution for any initial dye concentration.[36]

In the case of adsorption of crystal violet on vitreous tuff, the Freundlich isotherm gave the best fit to experimental data. The Freundlich equation (9) was used for $Q_{\mathrm{e}}$ calculation to obtain the amount of adsorbent need use to removal different dye removal percentage.

Figure 7 shows the required amount of vitreous tuff to reduce the crystal violet concentration in aqueous solution by $40 \%, 60 \%, 80 \%$, and $90 \%$ at various volumes of effluents. In the case of a single-stage batch adsorption system, the design procedure is now outlined. For example, to 


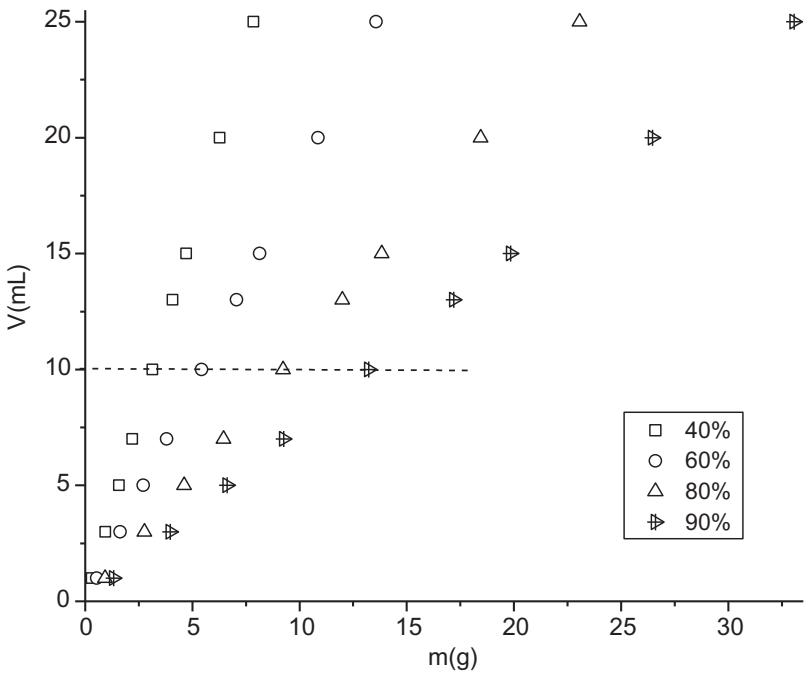

Figure 7. Adsorbent mass $(m)$ against volume of effluent $(\mathrm{V})$ treated for various percentages of dye removal at $432 \mathrm{mg} / \mathrm{g}$ initial crystal violet concentration.

Table 4. Comparisons of vitreous tuff adsorption capacity to crystal violet with other adsorbent materials.

\begin{tabular}{lcc}
\hline Adsorbent & $q_{\max }(\mathrm{mg} / \mathrm{g})$ & Reference \\
\hline $\begin{array}{l}\text { Sulphuric acid-activated } \\
\text { carbons from male flowers of }\end{array}$ & 85.84 & {$[38]$} \\
$\quad$ coconut tree & & \\
Palygorskite & 50.76 & {$[39]$} \\
Palm kernel fibre & 78.9 & {$[40]$} \\
Laminaria japonica (brown & 66.64 & {$[6]$} \\
$\quad$ algae) & & \\
Untreated rice bran & 41.68 & {$[6]$} \\
Wheat bran & 69.15 & {$[6]$} \\
Vitreous tuff & 174.01 & This work \\
\hline
\end{tabular}

remove $40 \%$ of dye in $10 \mathrm{~L}$ the amount of adsorbent required is four times lesser than obtain a $90 \%$ of dye removal in the same volume.

Assuming the batch adsorption to be a single-staged equilibrium operation, the separation process can be defined mathematically using the mass balance and the Freundlich equation to estimate the amount of adsorbent required to decrease the dye concentration in aqueous solution.[37]

\subsection{Comparison between the adsorption capacities for some adsorbents materials}

Table 4 shows the adsorption capacities for crystal violet using different adsorbents; it is difficult to compare the results of this work with those from the literature because the adsorption capacities were determined in different experimental conditions, depending on the dye concentration, chemical composition of adsorbent, etc. The adsorbent used in this study shows relatively good adsorption capacities compared with other adsorbent materials.
Alternatively, some studies have reported dye removal using similar tuff minerals such as zeolitic tuff. GutierrezSegura et al. [41] reported an adsorption capacity of $32.83 \mathrm{mg} / \mathrm{g}$ for indigo carmine removal in aqueous solution when the material was modified with iron metal.

\section{Conclusions}

Efficient removal of crystal violet from aqueous solution with a vitreous tuff from Magueyal deposit located in the eastern region of Cuba was achieved. Vitreous tuff is a mesoporous material with surface area relatively large for these types of amorphous materials. The kinetic model that best described the process was the pseudo-second-order model indicating that the possible removal mechanism was chemisorption on a material with a very rough surface. The experimental results of the sorption process were described by the Freundilch model, the adsorption capacity was $174.01 \mathrm{mg} / \mathrm{g}$, and the fixation of dye molecule was through the chemical-sorption process. The design of single-stage adsorber allows predicting the behaviour of the system for possible scale-up; the adsorption capacity was higher than other conventional adsorbent materials.

\section{Funding}

We acknowledge financial support from CONACYT scholarship [Grant No. 507915] for ABF and Universidad Autónoma del Estado de México, project 3211-2012 and PROMEP/103.5/13/6535 project.

\section{References}

[1] Gupta VK, Suhas VK. Application of low-cost adsorbents for dye removal - a review. J Environ Manage. 2009;90:23132342.

[2] Dulman V, Cucu-Man SM. Sorption of some textile dyes by beech wood sawdust. J Hazard Mater. 2009;162:1457-1464.

[3] Kumar R, Ahmad R. Biosorption of hazardous crystal violet dye from aqueous solution onto treated ginger waste (TGW). Desalination. 2011;265:112-118.

[4] Monash P, Pugazhenthi G. Adsorption of crystal violet dye from aqueous solution using mesoporous materials synthesized at room temperature. Adsorption. 2009;15:390-405.

[5] Srinivasan A, Viraraghavan T. Decolorization of dye wastewaters by biosorbents: a review. J Environ Manage. 2010;91:1915-1929.

[6] Chen F, Fang P, Gao Y, Liu Z, Liu Y, Dai Y. Effective removal of high-chroma crystal violet over TiO2-based nanosheet by adsorption-photocatalytic degradation. Chem Eng J. 2012;204-206:107-113.

[7] Nandi BK, Goswami A, Purkait MK. Removal of cationic dyes from aqueous solutions by kaolin: kinetic and equilibrium studies. Appl Clay Sci. 2009;42:583-590.

[8] Eren E, Afsin B. Investigation of a basic dye adsorption from aqueous solution onto raw and pre-treated bentonite surfaces. Dyes Pigments. 2008;76:220-225.

[9] Batista R, Martínez J, González EM, García A. Depósitos de rocas y minerales industriales en Cuba. Sus principales regularidades estructuro-formacionales y perspectivas, IGP, La Habana, Cuba; 2005. 
[10] Acemioğlu B. Batch kinetic study of sorption of methylene blue by perlite. Chem Eng J. 2005;106:73-81.

[11] Qiangshan J, Linxia F, Hongyan L, Peng L. Preparation of surface-vitrified micron sphere using perlite from Xinyang, China. Appl Clay Sci. 2011;53:745-748.

[12] Blanco-Flores A, Autie-Castro G, Rodríguez-Montes de Oca D, Ricardo-Paez S, López-Cordero R, Autie-Pérez A. Características superficiales de un vidrio volcánico cubano y remoción de $\mathrm{Cu}^{2+}$ desde disoluciones acuosas. Revista Latinoamericana de Recursos Naturales. 2009;5: 238-252.

[13] Orozco G, Rizo R. Depósitos de zeolitas naturales de Cuba. Acta geológica hispánica. 1998;33:335-349.

[14] Colectivo de autores. Rocas y minerales industriales de la República de Cuba. Instituto de Geología y Paleontología (IGP). La Habana, Cuba; 2011.

[15] Leofanti G, Padovan M, Tozzola G, Venturelli B. Surface area and pore texture of catalysts. Catal Today. 1998;41: 207-219.

[16] Mekhamer WK. Energy storage through adsorption and desorption of water vapour in raw Saudi bentonite, Arab J Chem. 2011. doi:10.1016/j.arabjc.2011.03.021.

[17] Mumpton FA, Clayton WO. Morphology of zeolites in sedimentary rocks by scanning electron microscopy. Clays Clay Miner. 1976;24:1-23.

[18] Giannetto G, Montes A, Rodríguez G. Zeolitas: características, propiedades y aplicaciones industriales. Caracas: Editorial Innovación Tecnológica; 2000.

[19] Chowdhury S, Mishra R, Saha P, Krushwaha P. Adsorption thermodynamics, kinetics and isosteric heat of adsorption of malachite green onto chemically modified rice husk. Desalination. 2001;265:159-168.

[20] Montes de Oca RD. Caracterización del Vidrio Volcánico de Ají de Calderas [Tesis de Licenciatura de Química]. Facultad de Química, Universidad de La Habana; 1990.

[21] Mathialagan T, Viraraghavan T. Adsorption of cadmium from aqueous solutions by perlite. J Hazard Mater B. 2002;94:291-303.

[22] Sakizci M, Alver BE, Alver O, Yorukoğullari E. Spectroscopic and thermal studies of bentonites from Unye, Turkey. J Molecular Struct. 2010;969:187-191.

[23] Uzio D. Textural characterization of catalysts. In. Lynch J, editor. Physics-chemical analysis of industrial catalysts. Paris: Edtion Technip; 2001. p. 5-26.

[24] Gregg SJ, Sing KSW. Adsorption, surface area and porosity. London: Academic Press; 1982.

[25] Blanco-Flores A, Autie-Castro G, López-Cordero R, YeeMadeira H, Contreras JL, Autie-Pérez M. Obtención y caracterización de carbones microporosos por activación física a partir de semillas de palma Veitchia Merriillii. Revista Latinoamericana de Recursos Naturales. 2011;7:1-14.

[26] Wang S, Zhu ZH. Effects of acidic treatment of activated carbons on dye adsorption. Dyes Pigments. 2007;75: 306-314.
[27] Alkan M, Karadaş M, Dŏgan M, Demirbaş Ö. Adsorption of CTAB onto perlite samples from aqueous solutions. J. Colloid Interf Sci. 2005;291:309-318.

[28] Silber A, Bar-Yosef B, Levkovitch I, Soryano S. pHdependent surface properties of perlite: effects of plant growth. Geoderma. 2010;158:275-281.

[29] Gutiérrez-Segura E, Solache-Ríos M, Colín-Cruz A, Fall C. Adsorption of cadmium by $\mathrm{Na}$ and Fe modified zeolitic tuffs and carbonaceous material from pyrolyzed sewage sludge. J Environ Manage. 2012;97:6-13.

[30] Allaboun H, Al-Rub FAA. Dynamics, mechanistic and equilibrium studies for the biosorption of nickel on palm tree leaves. Jordan J Civil Eng. 2008;2:124-138.

[31] Selatnia A, Madani A, Bakhti MZ, Kertous L, Mansouri Y, Yous R. Biosorption of Ni2+ from aqueous solution by a $\mathrm{NaOH}$-treated bacterial dead streptomyces rimosus biomass. Miner Eng. 2004;17:903-911.

[32] Collins KE, De Camargo RV, Dimiras BA, Menezes TCD, Da Silva AP, Collins $\mathrm{CH}$. Physisorbed wáter layer formation on fully hydroxylated mesoporous silicas. J Colloid Interf Sci. 2005;291:353-360.

[33] Porkodi K, Kumar VK. Equilibrium, kinetics and mechanism modeling and simulation of basic and acid dyes sorption onto jute fiber carbon: eosin yellow, malachite green and crystal violet single component systems. J Hazard Mater. 2007;143:311-327.

[34] Guiza S, Bagane M. External mass transport process during the adsorption of methyl violet onto sodic bentonite. J Univ Chem Technol Metal. 2012;47:283-288.

[35] Trgo M, Perić J. Interaction of the zeolitic tuff with $\mathrm{Zn}$ containing simulated pollutant solutions. J Colloid Interf Sci. 2003;260:166-175.

[36] Kumar VK, Porkodi K. Batch adsorber design for different solution volume/adsorbent mass ratios using the experimental equilibrium data with fixed solution volume/adsorbent mass ratio of malachite green onto orange peel. Dyes Pigments. 2007;74:590-594.

[37] Bulut E, Özacar M, Şengil İA. Equilibrium and kinetic data and process design for adsorption of Congo red onto bentonite. J Hazard Mater. 2008;154:613-622.

[38] Senthilkumaar S, Kalaamani P, Subburaam CV. Liquid phase adsorption of crystal violet onto activated carbons derived from male flowers of coconut tree. J Hazard Mater B. 2006;136:800-808.

[39] Al-Futaisi A, Jamrah A, Al-Hanai R. Aspects of cationic dye molecule adsorption to palygorskite. Desalination. 2007;214:327-342.

[40] El-Sayed GO. Removal of methylene blue and crystal violet from aqueous solutions by palm kernel fiber. Desalination. 2011;272:225-232.

[41] Gutierrez-Segura E, Solache-Rios M, Colin-Cruz A. Sorption of indigo carmine by a Fe-zeolitic tuff and carbonaceous material from pyrolyzed sewage sludge. J Hazard Mater. 2009;170:1227-1235. 